\title{
Weak C-H...O hydrogen bonds in alkaloids: An overview
}

\author{
RAJNIKANT*, DINESH and KAMNI \\ Post Graduate Department of Physics, University of Jammu, Jammu Tawi 180 006, India
}

MS received 1 March 2004; revised 15 December 2004

\begin{abstract}
An overview of general classification scheme, medicinal importance and crystal structure analysis with emphasis on the role of hydrogen bonding in some alkaloids is presented in this paper. The article is based on a general kind of survey while crystallographic analysis and role of hydrogen bonding are limited to only those alkaloids whose three-dimensional structure has been reported by us. The C-H...O hydrogen bonding in the solid state in alkaloids has been found to be predominant and this observation makes the role of hydrogen bonding in organic molecular assemblies very important.
\end{abstract}

Keywords. Alkaloids; crystallography; crystal structure; hydrogen bond.

\section{Introduction}

Defining what the term alkaloid means today is no easy task. The reason is that over 5000 alkaloids of all structural types are known. No other class of natural products possesses such an enormous variety of structures. Steroids, for example, are all modeled on a few skeletal types. The same holds true for triterpenes, flavonoids, coumarins, biphenyls or polysaccharides. But alkaloids exhibit dozens of different skeletal types. This situation causes an extraordinary difficulty in defining alkaloids so that they may be readily recognized and differentiated from other classes of nitrogen-containing compounds.

The term alkaloid was first coined in 1819 by a pharmacist, W. Meissner and meant simply, alkalilike (Middle English alcaly, from Medieval Latin alkali, from Arabic alqaliy $=$ ashes of saltwort, from qualey, to fry). The first modern definition by Winterstein and Trier (1910) describes these substances in a broad sense as basic, nitrogen-containing compounds of either plant or animal origin. "True alkaloids" were defined as compounds meeting the four additional qualifications that are (i) nitrogen atom may or may not be a part of a heterocyclic system, (ii) they have a complex molecular structure, (iii) these compounds manifests significant pharmacological activity and (iv) these are restricted to the plant kingdom.

Alkaloids occur as salts of plant acids such as malic, meconic or quinic acid. Some alkaloids occur in plants combined with sugars, whereas others are present as amides. Compounds satisfying the definition of true alkaloids are restricted to certain families and genera of plant king-

\footnotetext{
*Author for correspondence (rkantverma@ $@$ rediffmail.com)
}

dom, rarely being distributed in large group of plants. Though about $40 \%$ of all plant families contain atleast one alkaloid-bearing species, alkaloids have been reported in only $9 \%$ of over 10,000 plant genera. Chemical, pharmacological and botanical properties are usually considered when classifying a compound as an alkaloid. Other heterocyclic nitrogenous bases not classified as alkaloids by some authorities include the purines, of which caffeine, xanthine and bromine are few examples.

In view of the complexity of the compounds involved and for some historical reasons, the nomenclature of alkaloids has not been systematized even today. The two commonly used systems classify alkaloids either according to the plant genera in which they occur or on the basis of similarity in their molecular structures.

\subsection{General classification of alkaloids}

The concept regarding classification of alkaloids has changed now with the changing scientific out-look and scenario and the modern concept classify alkaloids into three main kinds as shown in the following diagrammatic scheme.
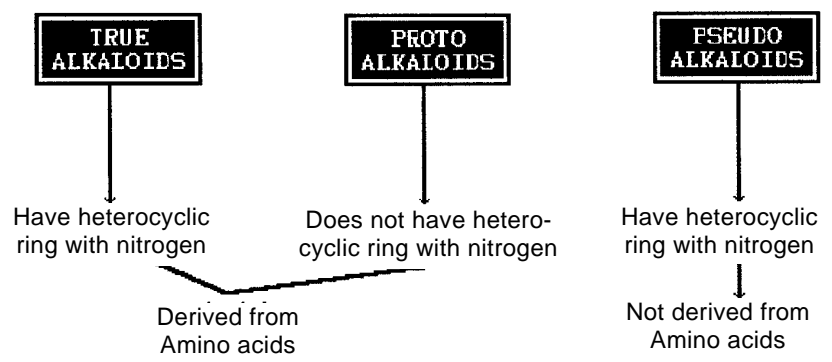
On the basis of chemical classification, numerous classes of alkaloids are possible:

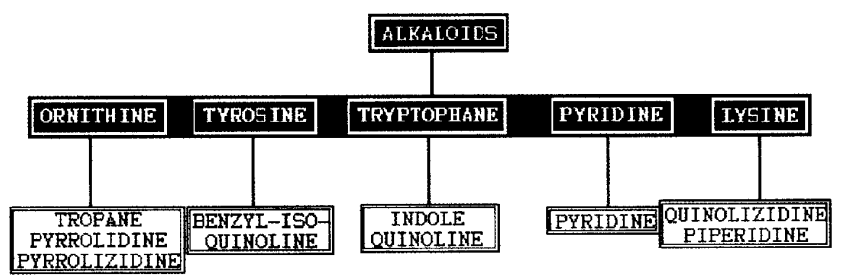

Although majority of alkaloids or their derivatives are colourless, crystalline, non-volatile solids, a few such as contine and nicotine are liquids and few are even coloured, e.g. berberine is yellow. The free bases (i.e. alkaloids themselves) are insoluble in water but soluble in most of the organic solvents. Most of the alkaloids are laevo-rotatory (optically active), although a few are dextro-rotatory (optically inactive) e.g. conine, papaverine etc. Generally, the alkaloids are bitter in taste and have pronounced physiological activity. Many of the alkaloids possess curative properties and are of much importance and relevance in medicines, but they are powerful poisons as well (Baker et al 1961).

\subsection{Isolation and pharmacological activity}

Many of the earliest isolated pure compounds with biological activity were alkaloids and it was due to the ease in the procedure of isolation. The nitrogen generally makes the compound basic and the compound exists in the plant as a salt. Thus alkaloids are often extracted with water or mild acid and then recovered as crystalline material by treatment with base. Most of them are nitrogen heterocycles which occur mainly in plants as their salts of common carboxylic acids such as citric, lactic, oxalic, acetic, malic and tartaric acids as well as fumaric, benzoic, aconitic and veratric acids. Their amine character produces an alkaline solution in water and hence the origin of their name-alkaloids.

The concentration of alkaloids in plants depend upon the season, age and its locality. It is interesting to note that closely related alkaloids generally occur together in the same plant. For instance, twenty alkaloids have been isolated from opium (Anshu Sawhney 2003). It is also observed that different genera of the same family may contain the same or structurally related alkaloids. It is found that simple alkaloids are often found in different plants whereas the complex alkaloids in one species or genus of a family.

Alkaloids are renowned for their potent and diverse pharmacological activities which include their clinical use such as analgesics, anti-malarial, anti-spasmotics, for pupil dilation, for the treatment of hypertension, mental disorders and tumours (Babita 1994). Many alkaloids have very great value in medical sciences because of the specific pharmacological action. A number of pyrrolizidine alkaloids have been found to cause severe lesions in the liver and lungs of both men and animals (Sharma 1985). The pyrrolizidine alkaloids have been investigated as anti-tumour agents and correlation between the lesions as cancer has also been studied (Mclean 1970). Morphine and some of its related compounds are the best known reagents for the relief of pain. Quinazoline derivatives possess hypotensive, analgesic and anticoagulant activities (Bergman et al 1986). Quinine, a poisonous derivative of alkaloid, is extensively used as antimalarial drug (Baker et al 1961). Quinazoline derivatives have been found effective against parasites (Berg and Lucas 1961). In addition to the uses of quinazoline in drugs, certain quinazoline derivatives particularly when condensed with amino anthraquinolines, act as useful dye-stuffs (Ebel et al 1958). Recent studies have shown some remarkable properties exhibited by a variety of quinazoline derivatives and most notable among these have found place in analgesics, antiallergic, anti-inflammatory, secretion, anticoagulant (Babita 1994), etc.

Alkaloids are used for the treatment of asthma, cough, tuberculosis (Thappa et al 1996), etc. Alkaloids are also widely being abused as a recreational drug. It causes a variety of pharmacological effects on the central nervous systems. The well known example is that of cocaine which when inhaled results in increased heart rate and blood pressure (Byke and Vandyke 1997). Carpaine is another such substance which is reported to be a kind of heart poison and it lowers the pulse frequency and depresses the central nervous system (Rajnikant 1988; Joshi et al 1996). It has also been seen that the nitrogen is an important component which plays an important role in the determination of activity of alkaloids.

\subsection{Aim of the present work}

The paper has been designed keeping in view not only the chemical or pharmacological aspects of alkaloids but the main thrust is to make a review of X-ray crystallographic studies, their findings and interpretation of the role of hydrogen bonding in this particular class of organic compounds. It is now an admitted fact that all those materials which exist in single crystal form need to be examined for knowing their internal architecture and the well accepted and known technique for determining the three-dimensional structure is X-ray crystallography. We have been working in this direction for the last over ten years and felt the need to put the whole data in the form of a compendium on a comparative scale so that the results may speak about what is missing in the literature. It appears to be an attempt of first of its kind where alkaloids are being discussed with particular reference to 
their X-ray crystallographic investigations and also with the following aims and objectives:

(I) Precise presentation of the crystal data of each molecule so as to know whether alkaloids do have any preference to exist in a particular crystal system or space group. (II) To ascertain whether the phenomenon of multiple molecules (asymmetric or crystallographically independent molecules) does exist in this class of materials.

(III) A comparison of some important structural and geometrical features of alkaloids.

(IV) A brief exposition of the possible role of nitrogen in alkaloids and their crystallographic comparison on a comparative scale.

(V) To examine the role of intra- and intermolecular hydrogen bonded interactions in alkaloids and find reasons for the predominance of one over another.

(VI) Determine the distance and angle cut-off criteria in case of various hydrogen bonds in alkaloids in the light of work as reported by Desiraju and Steiner (1999) and other researchers (Nishio and Hirota 1989; Aakeroy and Seddon 1993a,b; Nishio et al 1995, 1998; Aakeroy 1997).

\section{Brief crystallographic description about alkaloids and comparative crystallographic findings}

Presented below is the IUPAC name, chemical formula and reference of the alkaloids whose structures have been investigated and reported by us (Rajnikant et al 1993, 1996, 1998a,b, 2000, 2001a,b, 2002a,b; Magotra et al 1996).

\subsection{General experimental procedure involved in structure determination and refinement}

The preliminary X-ray photographic techniques such as oscillation, rotation and Weissenberg are employed to ascertain the crystalline nature of any grown material and this provides a first hand information to a crystallographer to move ahead for the collection of X-ray diffraction data using a computer-controlled single crystal X-ray diffractometer. Three-dimensional intensity data of a chosen crystal is collected on CAD-4 diffractometer by using either $\operatorname{CuK} \alpha(\lambda=1.5418 \AA)$ or $\operatorname{MoK} \alpha$ radiation $(\lambda=$ $0.71069 \AA) . \omega / 2 \theta$ scan mode is employed for data collection. The cell parameters are usually refined from accurately determined 25 reflections in a given $\theta$ range. Two reference reflections are generally monitored of every 100 reflections to check for crystal deterioration, if any, during beam exposure to the sample. The reflection data so obtained is usually raw in nature and is generally cleaned by applying various corrections. The reduced data thus becomes an input for structure determination by employing direct methods (Stout and Jensen 1968).

The molecular structures (mol. I-X) have been solved by direct methods using SHELXS86 software (Sheldrick 1986). Full-matrix least-squares refinement of organic structure is generally carried out by using SHELXL93 (Sheldrick 1993) and SHELXL97 (Sheldrick 1997a,b) softwares. The least-squares refinement of the positional $(x$, $y, z)$ and thermal parameters $\left(U_{\text {eq's }}\right)$ provide precision in location of various atoms and their thermal amplitudes. Statistically, the refinement technique provides treatment to our data so that precision in the observed and calculated values for various structural and geometrical parameters is obtained. This treatment helps us in obtaining a good model of the structure which should have a high level of confidence i.e. the chemical and computed structure should match at a level of confidence as close to 95$97 \%$ or in other words the reliability index i.e. $R$-factor, for a well refined structure should have a value between 3 and 5\%. All non-hydrogen atoms of the molecule are located from the E-map and all hydrogen atoms are either located or fixed stereo-chemically. Further refinement of the molecule with anisotropic thermal parameters provides the final yield of $R$-factor. In other words, $R$-factor is the average per cent error between observed and calculated $|F|$ or $F^{2}$ s and it is expressed as

$$
R=\frac{\sum|| F_{\mathrm{o}}|-| F_{\mathrm{c}} \mid}{\sum\left|F_{\mathrm{o}}\right|}
$$

where $F_{\mathrm{o}}$ and $F_{\mathrm{c}}$ are the magnitudes of the observed and

\begin{tabular}{|c|c|c|c|}
\hline $\begin{array}{l}\text { Mol. } \\
\text { no. }\end{array}$ & IUPAC name & Chemical formula & Reference \\
\hline I & $\beta$-hydrastine & $\mathrm{C}_{21} \mathrm{H}_{21} \mathrm{NO}_{6}$ & Rajnikant et al (1993) \\
\hline II & Water solvated tetrahydropalmatine hydrochloride & {$\left[\mathrm{C}_{21} \mathrm{H}_{26} \mathrm{NO}_{4}\right]^{+} \cdot \mathrm{Cl}^{-} \cdot \mathrm{H}_{2} \mathrm{O}$} & Rajnikant et al (1996) \\
\hline III & 7-methoxyvascinone hydrate & $\mathrm{C}_{12} \mathrm{H}_{12} \mathrm{~N}_{2} \mathrm{O}_{3} \cdot \mathrm{H}_{2} \mathrm{O}$ & Magotra et al (1996) \\
\hline IV & 1,2,3,4,5-pentahydro-azpino(2,1-b)quinazolin-11(1H)-one hydrochloride & $\mathrm{C}_{13} \mathrm{H}_{14} \mathrm{~N}_{2} \mathrm{O} \mathrm{HCl} \mathrm{H} \mathrm{H}_{2} \mathrm{O}$ & Rajnikant et al (1998a) \\
\hline V & Carpaine & $\mathrm{C}_{28} \mathrm{H}_{50} \mathrm{~N}_{2} \mathrm{O}_{4}$ & Rajnikant et al (1998b) \\
\hline VI & 5N-ethyl,8-carboxy,9-oxo-11-methyl-pyridol[2,1-b] quinazoline & $\mathrm{C}_{16} \mathrm{H}_{16} \mathrm{~N}_{2} \mathrm{O}_{3}$ & Rajnikant et al (2000) \\
\hline VII & Royline monohydrate & $\mathrm{C}_{25} \mathrm{H}_{41} \mathrm{NO}_{7} \cdot \mathrm{H}_{2} \mathrm{O}$ & Rajnikant et al (2001a) \\
\hline VIII & $\begin{array}{l}\text { Methyl-3,4-dihydro-3-(p-methylphenyl)-4-oxo-2-quinazolinyl } \\
\text { thiopropionate }\end{array}$ & $\mathrm{C}_{19} \mathrm{H}_{18} \mathrm{~N}_{2} \mathrm{O}_{3} \mathrm{~S}$ & Rajnikant et al (2001b) \\
\hline IX & 2-methyl-4-phenyl-3,4-dihydro-quinazolinium chloride & $\mathrm{J}_{2} \cdot \mathrm{HCl}$ & $l(2002 \mathrm{a})$ \\
\hline $\mathrm{X}$ & 4-phenylquinolin-2(1H)-one & $\mathrm{C}_{15} \mathrm{H}_{11} \mathrm{NO}$ & Rajnikant et al (2002b) \\
\hline
\end{tabular}


calculated structure factors. The weighing scheme is generally employed to have a flat analysis of variance in terms of $F_{\mathrm{c}}^{2}$. Atomic scattering factors are taken from International tables for Crystallography (1992, Vol. C, Tables $4 \cdot 2 \cdot 6 \cdot 8$ and $6 \cdot 1 \cdot 1 \cdot 4)$. Structural parameters such as bond distances, bond angles, torsion angles, dihedral angles between various planes of a given molecule etc are obtained from the PARST software (Nardelli 1983) and molecular modeling i.e. to obtain a general view of the molecule and plotting the molecules in the three dimensional environment in a unit cell is carried out with ORTEP software (Farrugia 1997).

\subsection{Brief crystallographic description of each investigated alkaloid}

A precise description of all the ten alkaloids is presented with more emphasis on the activity, medicinal importance, brief crystallographic data and some unique observations about each structure. Some selected $\mathrm{C}-\mathrm{N}(\AA)$ bond distances and $\mathrm{C}-\mathrm{N}-\mathrm{C}\left({ }^{\circ}\right)$ bond angles are presented in table 1 , while the data on hydrogen bonding is listed in tables 3 and 4, respectively. The general view and molecular packing have not been included since these details are already reported (Rajnikant et al 1993, 1996, 1998a,b, 2000, 2001a,b, 2002a,b; Magotra et al 1996).

(i) $\beta$-hydrastine: $\beta$-hydrastine (I) is a naturally occurring phthalideisoquinoline alkaloid and is used as an antiseptic and as a uterine hemostatic. It is isolated from Fumaria parviflora, crystallized as transparent prisms from alcohol (Rajnikant et al 1993). It is closely related to (-) $\alpha$-narcotine (Moss and Watson 1984) and bicuculline (Gorinsky and Moss 1973).

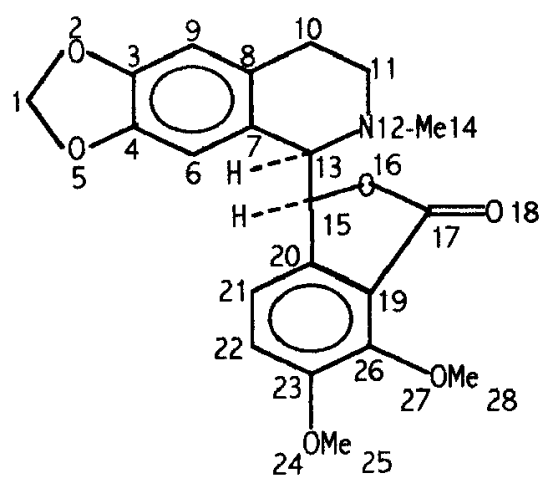

(I)

Chemical formula: $\mathrm{C}_{21} \mathrm{H}_{21} \mathrm{NO}_{6}$; cell parameters: $a=7 \cdot 542(2)$, $c=33 \cdot 266(2) \AA$; unit cell volume: $1892 \AA^{3}$; crystal system/ space group: tetragonal $/ \mathrm{P}_{3}$; no. of molecules per unit cell $(Z)$ : 4 ; radiation used $(\mathrm{CuK} \alpha, \lambda): 1.5405 \AA$; no. of measured reflections: 2129 ; $R$-factor: $0 \cdot 061$.
The N-heterocyclic ring has bond distances and angles comparable with the literature values (Cameron et al 1974; Bruderer et al 1976; Wong and Nyburg 1979). Molecular packing in the unit cell is typical of tetragonal system (Rajnikant et al 1993). In hydrastine the dihedral angle between plane 1 [C1-O2-C3-C9-C8-C10-C11N12-C13-C7-C6-C4-O5] and plane 2 [C15-O16-C17$\mathrm{C} 19-\mathrm{C} 26-\mathrm{C} 23-\mathrm{C} 22-\mathrm{C} 21-\mathrm{C} 20]$ is $42.9^{\circ}$, while the magnitude of torsion present along $\mathrm{C} 13-\mathrm{C} 15$ bond is $-55 \cdot 2^{\circ}$. This may be due to the presence of $\mathrm{N}-\mathrm{CH}_{3}$ group and a five-membered ring at $\mathrm{C} 15$ position.

(ii) Water solvated tetrahydro-palmatine hydrochloride: The compound (II) has been isolated from the roots of Stephania glabra (Gupta and Banerjee 1994), a shrub growing in tropical and temperate Himalayas at an altitude of 7,000 ft. above the sea level. The roots of this shrub are considered to be useful in the treatment of tuberculosis, asthma, dysentery and intestinal complaints. It is widely used by the hill tribes of Assam in India as a household remedy for the said disease (Chopra 1958).

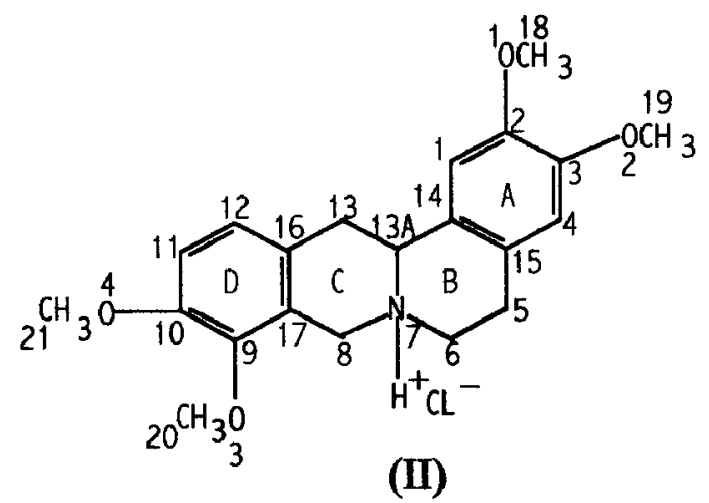

Chemical formula: $\left[\mathrm{C}_{21} \mathrm{H}_{26} \mathrm{NO}_{4}\right]^{+} \cdot \mathrm{Cl}^{-} \cdot 2 \mathrm{H}_{2} \mathrm{O}$; cell parameters: $a=6.879(1), b=11.977(1), c=13.088 \AA, \beta=95.33(1)^{\circ}$; unit cell volume: $1073.65 \AA^{3}$; crystal system/space group: Monoclinic/ $P 2_{1}$; no. of molecules per unit cell $(Z)$ : 2 ; radiation used $(\mathrm{MoK} \alpha, \lambda)$ : $0.71073 \AA$; no. of measured reflections: $2050 ; R$ factor: $0 \cdot 051$.

The two phenyl rings $A$ and $D$ having methoxy substitutions at $\mathrm{C} 2, \mathrm{C} 3$ and $\mathrm{C} 9, \mathrm{C} 10$ are planar. Ring-B exists in half-chair conformation with the rotational axes bisecting the C6-N7 and C14-C15 bonds with asymmetry parameter $\Delta \mathrm{C}_{2}(\mathrm{C} 6-\mathrm{N} 7)=3 \cdot 31$ (Duax and Norton 1975). Ring $\mathrm{C}$ also adopts half-chair conformation with the rotational axis bisecting the N7-C13A and $\mathrm{C} 16-\mathrm{C} 17$ bonds; $\Delta \mathrm{C}_{2}$ $(\mathrm{N} 7-\mathrm{C} 13 \mathrm{~A})=4 \cdot 01$. The $\mathrm{C} 18, \mathrm{C} 19$ and $\mathrm{C} 21$ methoxyl groups are nearly coplanar with their respective phenyl rings, $A$ and $D$, while $C 20$ is rotated out of the plane of ring $D$ by $114 \cdot 0(6)^{\circ}$. The cation and chloride anion are connected by a hydrogen bond involving $\mathrm{H} 7$ at N7. Intra- and intermolecular $\mathrm{C}-\mathrm{H}$...O hydrogen bonds contribute to the stability of molecules in the unit cell (Rajnikant et al 1996). 
(iii) 7-Methoxyvasicinone hydrate: The compound (III) has been isolated from the leaves of Adhatoda vasica (Nees), a highly reputed ayurvedic medicinal plant used for the treatment of asthma, bronchitis and tuberculosis (Mehta et al 1963). Leaves of Adhatoda vasica were extracted with ethanol at room temperature (Magotra et al 1996).

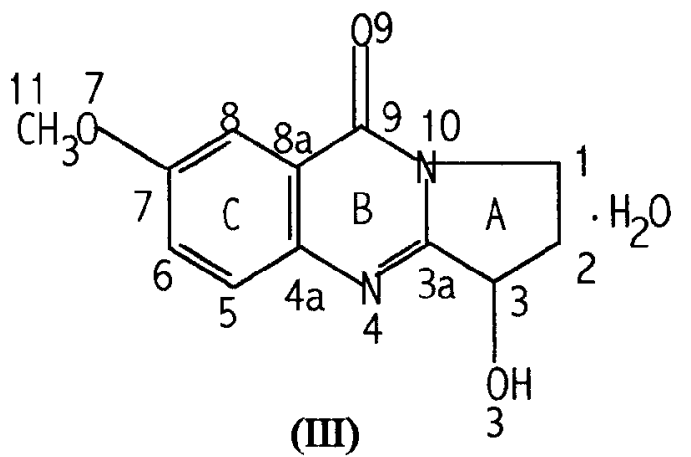

Chemical formula: $\mathrm{C}_{12} \mathrm{H}_{12} \mathrm{~N}_{2} \mathrm{O}_{3} \cdot \mathrm{H}_{2} \mathrm{O}$; cell parameters: $a=7 \cdot 630(1)$, $b=35 \cdot 156(5), c=8 \cdot 505(1) \AA$; unit cell volume: $2281.4 \AA^{3}$; crystal system/space group: orthorhombic/Pbca; no. of molecules per unit cell $(Z)$ : 8; radiation used $(\mathrm{MoK} \alpha, \lambda)$ : 0.71073 no. of measured reflections: $3145 ; R$-factor: 0.049.

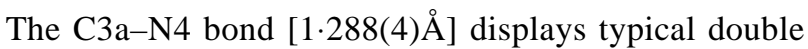
bond character. The $\mathrm{N}-\mathrm{C}-\mathrm{N}$ angle is $125 \cdot 2(3)^{\circ}$. Generally this bond angle has been found to be greater than $120^{\circ}$ in most pyrimidine and quinazoline compounds (Stroud 1973). The least-squares planes and torsion angle calculations indicate strict planarity for the phenyl ring and the methoxy group is coplanar with it. The pyrimidine ring deviates slightly from planarity [with a maximum deviation from the plane of 0.023(4) $\AA$ for C9]. The five-membered ring has an intermediate half-chair/envelope conformation with a phase angle of pseudorotation $\delta=53.95^{\circ}$ and a maximum torsion angle of $27.72^{\circ}$. Atom $\mathrm{O} 3$ attached to C3 is 1.472 (3) $\AA$ above the plane defined by the atoms of the fused ring system. The crystal structure is stabilized by two O-H...O type intermolecular contacts involving water molecule of crystallization (Magotra et al 1996).

(iv) 1,2,3,4,5-Pentahydroazepino (2,1-b) quinazolin-11 (1H)-one hydrochloride with water molecule: The compound (IV) has been synthesized by condensing $\delta$ valerolac-tam(2-piperidone) and caprolactam (6-aminocaproic acid lactam), respectively, with anthranilic acid in the presence of $\mathrm{P}_{2} \mathrm{O}_{5}$ and xylene (Rajnikant et al 1998a). It possesses potent bronchodilatory activity (Atal 1980).

The rings $\mathrm{A}$ and $\mathrm{B}$ are planar. The length of C13-N6 bond $[1 \cdot 335(1) \AA]$ indicates the double bond character. The N-C-N bond angle $\left(120 \cdot 7^{\circ}\right)$ is considerably less in magnitude as compared to the values reported for some analogous structures (Kistenmacher and Shigematsu 1974; Picorari et al 1992; Sharma et al 1993). However, the bond angles $\mathrm{C} 13-\mathrm{N} 6-\mathrm{C} 15\left[122 \cdot 1(8)^{\circ}\right]$ and $\mathrm{C} 11-\mathrm{N} 14-$

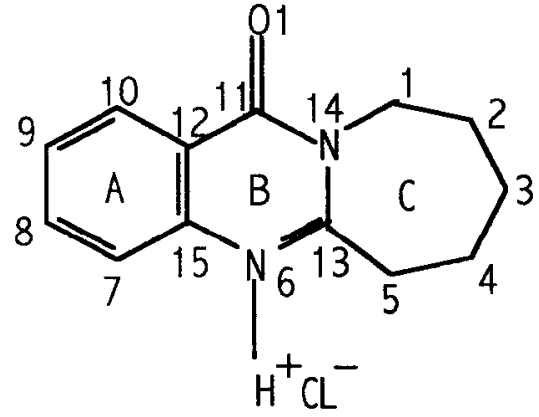

(IV)

Chemical formula: $\mathrm{C}_{13} \mathrm{H}_{14} \mathrm{~N}_{2} \mathrm{O} \mathrm{HCl} \mathrm{H}_{2} \mathrm{O}$; cell parameters: $a=6 \cdot 251, b=10 \cdot 383, c=19 \cdot 970 \AA$; unit cell volume: $1296 \cdot 14 \AA^{3}$; crystal system/space group: orthorhombic/P2 $2_{1} 2_{1} 2_{1}$; no. of molecules per unit cell $(Z)$ : 4 ; radiation used $(\mathrm{CuK \alpha}, \lambda)$ : $1.5418 \AA$; no. of measured reflections: $1152 ; R$-factor: $0 \cdot 069$.

$\mathrm{C} 13\left[122 \cdot 4(8)^{\circ}\right]$ possess slightly large values. The mean value of bond length and bond angle for the sevenmembered heterocyclic ring $\mathrm{C}$ is $1.482(15) \AA$ and $116 \cdot 2(9)^{\circ}$, respectively. This ring deviates significantly from planarity (maximum deviation being $0 \cdot 272(12) \AA$ for $\mathrm{C} 4$ ) and hence the deviation makes this ring to exist in chair conformation with a pseudo mirror through C3 and bisecting the $\mathrm{C} 13-\mathrm{N} 14$ bond. The dihedral angle between the plane of ring $\mathrm{A}$ and $\mathrm{B}$ is $3.5(4)^{\circ}$ while it is $25.7(3)^{\circ}$ between the plane of ring $\mathrm{B}$ and $\mathrm{C}$. The chlorine atom of the hydrochloride is not involved in any intermolecular interaction and the crystal structure is stabilized by van der Waals interactions (Rajnikant et al 1998a).

(v) Carpaine: Isolation of carpaine (V) has been reported from the leaves of Carica papaya L family Enphorpiaceae, a subherbaceous and almost branchless tree found throughout India (Govindachari et al 1965). Carpaine, an alkaloid present in papaya leaves, can be used as a heart-rate depressant. It is also reported to be a potent amoebicide and diuretic (Choudhary and Panda 2003).

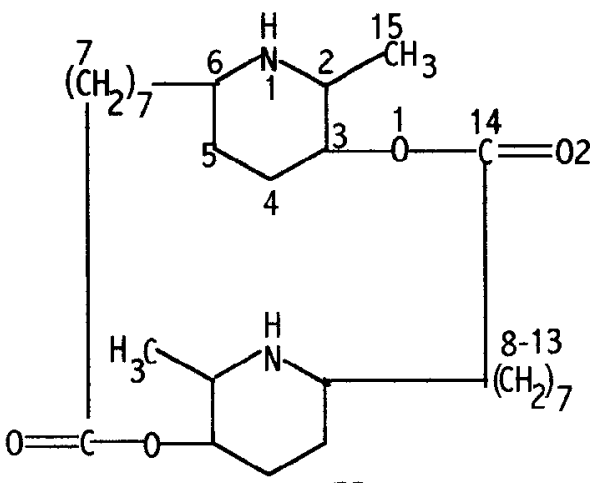

(V)

Chemical formula: $\mathrm{C}_{28} \mathrm{H}_{50} \mathrm{~N}_{2} \mathrm{O}_{4}$; cell parameters: $a=18 \cdot 695(2)$, $b=14.474(2), c=5 \cdot 474(1) \AA$; unit cell volume: $1481.2 \AA^{3}$; crystal system/space group: orthorhombic/P2 $2_{1} 2_{1} 2_{1}$; no. of molecules per unit cell $(Z)$ : 2; radiation used $(\operatorname{MoK} \alpha, \lambda)$ : 0.71073 $\AA$; no. of measured reflections: $1558 ; R$-factor: $0 \cdot 050$. 
The stereochemistry of the side chain at C6 and the presence of $\mathrm{CH}_{3}$ at $\mathrm{C} 2$ in carpaine molecule is reported to be cis (Govindachari and Narasimhan 1955). Models suggested by Govindachari et al (1965) indicate that the dimeric carpaine molecule is flexible and the two piperidine rings can assume the chair forms without restraint. The asymmetric parameter calculation for the piperidine ring clearly indicates that this ring adopts chair conformation with best rotational axis bisecting N1-C6 and C3-C4 bonds, with $\Delta \mathrm{C}_{2}(\mathrm{~N} 1-\mathrm{C} 6)=3 \cdot 183 \AA$ and the best mirror passing through $\mathrm{N} 1$ and $\mathrm{C} 4$, with $\Delta \mathrm{C}_{\mathrm{S}}(\mathrm{N} 1-\mathrm{C} 4)=$ $1 \cdot 278(38)$. In nature, there exists only half of the carpaine molecule in the unit cell and the remaining half of it was generated by employing computational techniques. The molecules in the unit cell adopt herringbone configuration and are stabilized by $\mathrm{N}-\mathrm{H}$... O and $\mathrm{C}-\mathrm{H}$...O intermolecular hydrogen bonds (Rajnikant et al 1998b).

(vi) 5N-ethyl, 8-carboxy, 9-oxo-11-methyl-pyridol[2,1-b] quinazoline: The compound (VI) has been prepared by refluxing 2,4-dimethyl-2,3-dihydroquinazoline and diethyl ethoxy methylene malonate (Mahajan 1995). These compounds possess significant biological properties such as anti-inflammatory, anti-coagulant, analgesic (Babita 1994) etc.<smiles></smiles>

(V)

Chemical formula: $\mathrm{C}_{16} \mathrm{H}_{16} \mathrm{~N}_{2} \mathrm{O}_{3}$; cell parameters $a=9 \cdot 775(1)$, $b=15 \cdot 868(1), c=9 \cdot 799(1) \AA, \beta=113 \cdot 50(1)^{\circ}$; unit cell volume: $1393.9 \AA^{3}$; crystal system/space group: monoclinic/ $P 2_{1} / c$; no. of molecules per unit cell $(Z)$ : 4; radiation used $(\mathrm{CuK} \alpha, \lambda)$ : $1.5418 \AA$; no. of measured reflections: $2852 ; R$-factor: 0.048 .

The mean values of two $\mathrm{C}\left(s p^{2}\right)-\mathrm{N}$ bonds i.e. N5-C13 and $\mathrm{N} 5-\mathrm{C} 14$, are in agreement with the standard value (Allen et al 1987). The length of the bond N5-C13 is close to the values obtained in E- and Z-isomers of 1-(2amino-1-cyano-2-thioethylene) pyridinium-ylide (Fischer et al 1983). The $\mathrm{C} 9=\mathrm{O} 3$ bond length $[1 \cdot 255(2) \AA]$ is

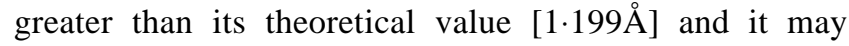
probably be due to the strong intramolecular O2$\mathrm{H} 17$...O3 hydrogen bond. The benzene ring is perfectly planar and the pyridone ring deviates slightly from pla- narity [maximum deviation is $-0.023 \AA$ for the $\mathrm{C} 14$ atom]. The pyrimidine ring has an $11 \beta$-sofa conformation with the asymmetry parameter $\Delta \mathrm{C}_{\mathrm{s}}[\mathrm{C} 11=0 \cdot 87(38)]$. The dihedral angle between the least-squares planes of benzene and pyridone rings is $28 \cdot 61(5)^{\circ}$, indicating that the molecule is somewhat folded, may be due to the sofa conformation of the pyrimidine ring. The molecular packing in the unit cell is of herringbone type and molecules are stabilized by three intramolecular and three intermolecular hydrogen bonds (Rajnikant et al 2000).

(vii) Royline monohydrate: The compound (VII) is a diterpenoid alkaloid isolated from Inula royleana, a shrub growing in the western temperate Himalayas at an altitude of 7000-12000 ft above the sea level (Rajnikant et al 2001a). The plant is considered to be poisonous and is used as a disinfectant and an insecticide. It is known to be commonly used against the head louse (Chopra et al 1945).

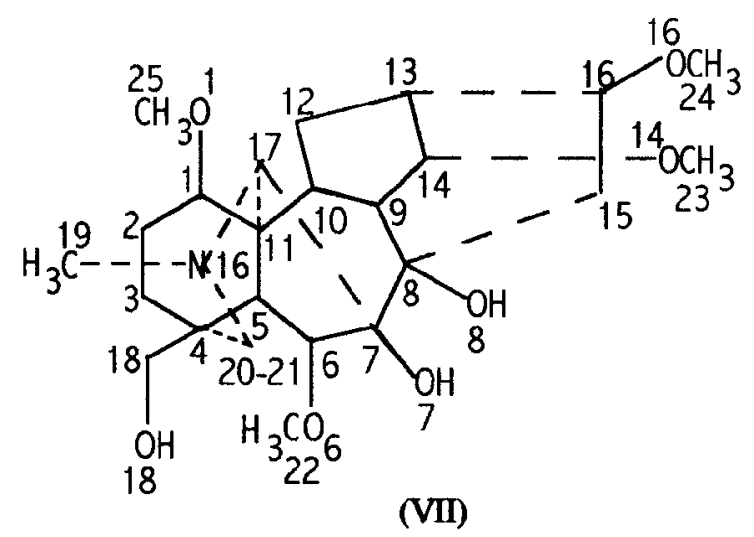

Chemical formula: $\mathrm{C}_{25} \mathrm{H}_{41} \mathrm{NO}_{7} \cdot \mathrm{H}_{2} \mathrm{O}$; cell parameters: $a=10 \cdot 985(1)$, $b=7 \cdot 898(1), c=14.956(1) \AA, \beta=102 \cdot 96(1)^{\circ}$; unit cell volume: $1264.52 \AA^{3}$; crystal system/space group: monoclinic $/ P 2_{1}$; no. of molecules per unit cell $(Z)$ : 2 ; radiation used $(\operatorname{MoK} \alpha, \lambda)$ : $0.71073 \AA$; no. of measured reflections: 2399 ; $R$-factor: 0.033 .

The geometric parameters of the molecule, i.e. bond lengths and bond angles, are quite close to the literature values (Bhandary et al 1990; Joshi et al 1992). The central ring system of royline is formed by the fusion of four six-membered and two five-membered rings. The mean value of three $\mathrm{C}\left(s p^{3}\right)-\mathrm{N}$ bonds $[1 \cdot 465(11) \AA]$ is comparable with the corresponding values obtained in the case of Delvestine (Bhandary et al 1990) and Delsoline (Joshi et al 1992). Rings A, B and C exist in distorted chair conformations whereas ring $\mathrm{D}$ acquires half-boat, ring $\mathrm{E}$ adopts half-chair and ring $\mathrm{F}$ occurs in $\mathrm{C}(14)$-envelope conformations. The molecular packing of royline in the unit cell when viewed down $b$-axis makes it amply clear that the molecule is folded within itself. Molecular folding of this kind is generally observed in molecules having multiple ring structures and it is mainly attributed to the 
distortions developed in individual ring systems. The crystal structure is stabilized by the $\mathrm{O}-\mathrm{H}$... O type intermolecular contacts involving the molecule of crystal water (Rajnikant et al 2001a).

(viii) Methyl-3,4-dihydro-3-(p-methylphenyl)-4-oxo-2-quinazolinyl thiopropionate: Alkaloids containing a quinazoline moiety are known for their biological properties (Babita 1994) and possess analgesic, antiallergic, antiinflammatory, secretion inhibition, anticoagulant properties (Baker et al 1961; Siegfied et al 1992). The compound (VIII) has been synthesized by adding a solution of 3-( $p$-methylphenyl)-2-thio-quinazoline-4(1H) one, methyl-2-chloropropionate $(0 \cdot 1 \mathrm{~mol})$ in acetone $(50 \mathrm{ml})$ with potassium carbonate $(1.5 \mathrm{~g})$ and the reaction mixture refluxed further for $15 \mathrm{~h}$ in an oil bath. The solvent was removed under reduced pressure to get a solid which has been recrystallized from ethanol (Rajnikant et al 2001b).

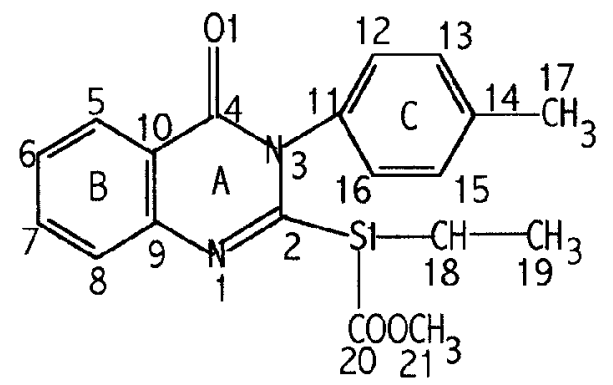

(VIII)

Chemical formula: $\mathrm{C}_{19} \mathrm{H}_{18} \mathrm{~N}_{2} \mathrm{O}_{3} \mathrm{~S}$; cell parameters: $a=9 \cdot 094(2)$, $b=9.428(3), c=10.612(3) \AA ; \alpha=94.55(3), \beta=95.44(2), \gamma=$ $106 \cdot 75(3)^{\circ}$; unit cell volume: $861.9 \AA^{3}$; crystal system/space group: triclinic/ $P \overline{1}$; no. of molecules per unit cell $(Z)$ : 2 ; radiation used $(\mathrm{MoK} \alpha, \lambda): 0.71073 \AA$; no. of measured reflections: 3233; $R$-factor: $0 \cdot 054$.

Rings A and B of the quinazoline moiety adopt almost planar conformations with the average value of torsion angles being $1.9(3)$ and $1.4(4)^{\circ}$, respectively. The phenyl ring $\mathrm{C}$ also exists in planar conformation with average value of torsion angles $0 \cdot 8(4)^{\circ}$. The ketone group located at $\mathrm{C} 4$ is deviated from the mean plane of ring $\mathrm{A}$ by $0 \cdot 050$ (3) $\AA$ and methyl group at C14 is deviated from the mean plane of ring $\mathrm{C}$ by $0 \cdot 036(3) \AA$. The conformational designations across the single bonds N1-C2-S1-C18, $\mathrm{C} 2-\mathrm{S} 1-\mathrm{C} 18-\mathrm{C} 20, \mathrm{~S} 1-\mathrm{C} 18-\mathrm{C} 20-\mathrm{O} 2$ and O2-C20-O3$\mathrm{C} 21$ of thiopropionate chain at $\mathrm{C} 2$ position of quinazoline are + synperiplanar, - synclinal, - synclinal and + synperiplanar (Klyne and Prelog 1996), respectively. The molecules in the unit cell are held in reversed orientations. The crystal structure is stabilized by an intermolecular interaction C7-H7...O2 (Rajnikant et al 2001b).

(ix) 2-methyl-4-phenyl-3,4-dihydro-quinazolinium chloride: The compound (IX) has been synthesized by an in- teraction of $\mathrm{N}$-acylated $\mathrm{o}$-aminoacetophenone with formamide or $N$-methylformamide in $85 \%$ formic acid. The reaction mixture was refluxed for $6-7 \mathrm{~h}$, cooled, diluted with water, basified with $\mathrm{NH}_{4} \mathrm{OH}$ and extracted with chloroform. The chloroform extract was dried over anhydrous $\mathrm{Na}_{2} \mathrm{SO}_{4}$ and distilled in vacuo. The product obtained was crystallized from ethanol (Suri et al 1993; Rajnikant et al 2002a). It possesses important biological activities such as anti-allergic, anti-coagulant, anti-inflammatory, analgesic, secretion inhibition (Babita 1994) etc.

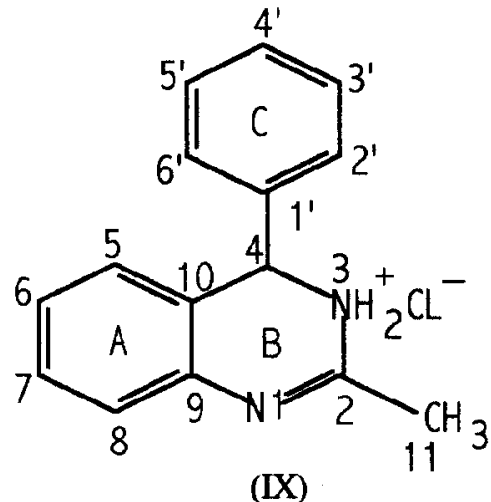

Chemical formula: $\mathrm{C}_{15} \mathrm{H}_{14} \mathrm{~N}_{2} \cdot \mathrm{HCl}$; cell parameters: $a=9 \cdot 682(1)$, $b=10 \cdot 532(1), c=13 \cdot 139(1) \AA, b=90 \cdot 82(2)^{\circ}$; unit cell volume: $1774.32 \AA^{3}$; crystal system/space group: monoclinic/ $P 2_{1} / c$; no. of molecules per unit cell $(Z)$ : 4 ; radiation used $(\mathrm{CuK} \alpha, \lambda)$ : $1.5418 \AA$; no. of measured reflections: $1364 ; R$-factor: $0 \cdot 057$.

The rings $\mathrm{A}$ and $\mathrm{B}$ are planar with maximum deviation of 0.003(5) and 0.007(4) $\AA$, respectively. The dihedral angle between these rings is $0 \cdot 5(1)^{\circ}$ confirming strict planarity of the fused ring system. In phenyl ring $\mathrm{C}$ which is also planar, its twist with respect to rest of the molecule as characterized by the torsion angle $\mathrm{N} 3-\mathrm{C} 4-\mathrm{C1}^{\prime}-\mathrm{C}^{\prime}$ is $137 \cdot 6(4)^{\circ}$. The twist is further confirmed by the corresponding torsion angle $\mathrm{N} 3-\mathrm{C} 4-\mathrm{C}^{\prime}-\mathrm{C} 2^{\prime} \quad\left(-43 \cdot 5^{\circ}\right)$. The dihedral angle between the plane of ring $\mathrm{C}$ and the quinazoline moiety is $79.3(1)^{\circ}$. In the unit cell molecules are stacked in reversed orientations along $b$-axis. An intermolecular hydrogen bond $\mathrm{N} 3-\mathrm{H} 3 \ldots \mathrm{C} 11$ between the chloride anion and nitrogen atom (N3) of the cation is responsible for the stability of the molecules in the unit cell (Rajnikant et al 2002a).

(x) 4-phenylquinolin-2(1H)-one: Alkaloids containing a quinoline possess high antibacterial, antirrhythmic and antihypertensive activities (Jones 1977; Yates 1984; Zacharias and Glusker 1988; Hua et al 1997; Newell et al 1998). The compound (X) was synthesized by adding a mixture of aniline $(0.1 \mathrm{~mol})$ and benzoyl acetate $(0.1 \mathrm{~mol})$ in dioxane $(50 \mathrm{ml})$ in a round bottomed flask, heated with reflux condenser for $3 \mathrm{~h}$ or $4 \mathrm{~h}$ in an oil bath, cooled and neutralized with sodium carbonate. The separated oil was extracted in chloroform. Removal of the 
solvent under vacuum gave heavy oil, which was distilled under reduced pressure. A mixture of benzoylacetanilide $(0 \cdot 1 \mathrm{~mol})$ and concentrated $\mathrm{H}_{2} \mathrm{SO}_{4}(20 \mathrm{ml})$ was heated on an oil bath with stirring at $70-80^{\circ} \mathrm{C}$ for $30 \mathrm{~min}$ and at $100^{\circ} \mathrm{C}$ for $1 \mathrm{~h}$, then cooled and poured in ice water $(500 \mathrm{ml})$ with continuous stirring. The resultant solid was filtered off and recrystallized from ethanol (Rajnikant et al 2002b).

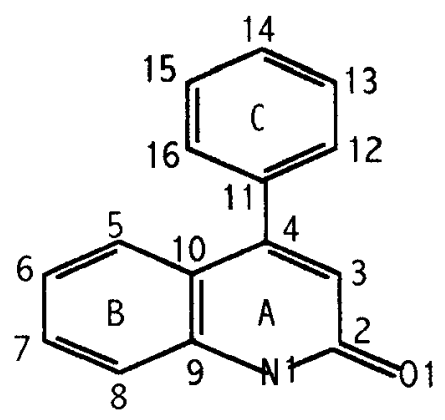

(X)

Chemical formula: $\mathrm{C}_{15} \mathrm{H}_{11} \mathrm{NO}$; cell parameters: $a=7 \cdot 382(2)$, $b=21 \cdot 795(3), c=14 \cdot 066(5) \AA$; unit cell volume: $2263 \cdot 1 \AA^{3}$; crystal system/space group: orthorhombic/Pbca; no. of molecules per unit cell $(Z)$ : 8; radiation used $(\operatorname{MoK} \alpha, \lambda)$ : $0.71073 \AA$; no. of measured reflections: 1987 ; $R$-factor: 0.039.

The mean bond lengths $\mathrm{C}\left(s p^{2}\right)-\mathrm{N}[1 \cdot 369(3) \AA]$ are quite close to their theoretical values (Sutton 1965). Rings A and B of quinoline moiety adopt almost planar conformations with average torsion angles of $1 \cdot 2(3)^{\circ}$ and $1.0(3)^{\circ}$, respectively. The phenyl ring $\mathrm{C}$ also exists in a planar conformation with an average torsion angle of $0.6(4)^{\circ}$ and shows a dihedral angle of $64.65(6)^{\circ}$ with the quinoline moiety. The unit cell packing of the molecules down $a$-axis shows that the molecules are overlapped in paired configuration. The molecular structure is stabilized by intermolecular C-H...O and N-H...O interactions (Rajnikant et al 2002b).

\section{Comparative crystallographic findings and the role of hydrogen bonding in alkaloids}

Looking at the source of synthesis/isolation of all the ten alkaloidal molecules and, of course, the medicinal/pharmacological activity they exhibit, precise crystallographic data along with chemical structure and atomic numbering scheme, followed by the salient features of each structure, provides us first hand information about the crystal system these molecules have preference for. In the present case, alkaloids have shown their first preference to exist in monoclinic and orthorhombic crystal systems.

The phenomenon of multiple molecules in the asymmetric unit cell is completely ruled out but for the excep- tion that only half molecule of carpaine exists in the unit cell (Rajnikant et al 1998b). This observation, however, is not true in case of some other organic molecular assemblies (Rajnikant et al 1995a,d; Rajnikant 2001).

In three-dimensional structure of these molecules (Rajnikant et al 1993, 1996, 1998a,b, 2000, 2001a,b, 2002a,b; Magotra et al 1996) where in some cases the geometrical parameters like bond distances and bond angles do agree with the values reported for their analogous structures while in some cases these parameters are worth comparison. The accuracy in the measurement of $h k l$ reflections and their corresponding intensities is indicative of a better data resolution $(\sin \theta / \lambda)$ while the precision in the calculation of molecular parameters is indicative of better yield of the reliability index. In the present case the reliability index ranges from 0.033-0.069 which itself speaks about the crystal quality, data collection, structure determination and refinement. Some of the important $\mathrm{C}-$ $\mathrm{N}$ distances and $\mathrm{C}-\mathrm{N}-\mathrm{C}$ bond angles in the reported molecules are presented in table 1 . The following observations can be drawn from the compared data: (i) The C$\mathrm{N}$ distances as obtained in all the ten alkaloids present a wide range of values falling between 1.059 and $1.517 \AA$. The broad spectrum of $\mathrm{C}-\mathrm{N}$ distances shows that, depending upon the nature and position of the substituent or the presence of ring system in its closer proximity, this bond is able to accommodate the torsion in and around the surrounding bonds caused due to the influence of neighbouring atoms. The $\mathrm{C}-\mathrm{N}$ distance appears to be more flexible than standard $\mathrm{C}-\mathrm{C}, \mathrm{C}=\mathrm{C}, \mathrm{C} \equiv \mathrm{C}$ distances which are quite fixed and do not vary under ordinary conditions and (ii) the magnitude of the $\mathrm{C}-\mathrm{N}-\mathrm{C}$ bond angle (i.e. all those angles in which nitrogen is held in the ring moiety) varies abnormally from $109 \cdot 0-128 \cdot 0^{\circ}$. It could be attributed to the same fact as stated above that nitrogen when substituted for a carbon atom in the ring structure adopts more flexibility in view of the torsional magnitude of the neighbouring bonds.

\subsection{Analysis of hydrogen bonding in alkaloids}

Covalently bonded atoms often produce a configuration that behaves like an electric dipole. Several such dipoles may be bonded together as a result of electrostatic attraction between them. The dipole bond in which hydrogen atom acts as the positive end of the dipole is known as hydrogen bond. Hydrogen bonding is usually formed between the most electronegative atoms like fluorine, oxygen and nitrogen because these atoms produce strong dipoles (Wahab 1999). In a hydrogen bond X-H...A, the functional group $\mathrm{X}-\mathrm{H}$ is called the 'donor' (sometimes called 'proton donor') and A is called the 'acceptor'. The bond may be described in terms of the $d, D, \theta$ and $r$ and if the hydrogen bond is extended on the acceptor side as $\mathrm{X}-\mathrm{H}$...A-Y, an acceptor angle $\phi, \mathrm{H}$...A-Y may also be 
defined (Desiraju and Steiner 1999) as shown in the diagram below

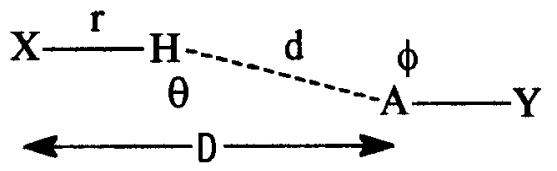

(Definition of the geometrical parameters $d, D, \theta, r$ and $\phi$ for a hydrogen bond)

Due to the long range character of the hydrogen bond, and to a pronounced softness of the angle at $\mathrm{H}$, donors may interact simultaneously with more than one acceptor. (i)<smiles>[Y][V]</smiles><smiles>[X]C([AlH2])[AlH2]</smiles>

(ii)<smiles>[X]C1CC1</smiles>

(iii)
To distinguish the different resulting configurations, (i) is called a two-centre bond because the H-atom is bonded to two atoms, $\mathrm{X}$ and $\mathrm{A}$, and analogously (ii) is called a three-centre, and (iii) a four-centre bond. The patterns (ii) and (iii) are often called bifurcated hydrogen bond and trifurcated hydrogen bond (Steiner 1995), respectively.

Hydrogen bonds are classified into two groups viz. intramolecular and intermolecular. Intramolecular hydrogen bonding occurs within two atoms of the same molecule while in intermolecular hydrogen bonding two or more than two molecules of the same or different compounds combine to give a polymeric aggregate.

The study of interactions in organic molecules has attracted the attention of crystallographers during the past two decades (Pimentel and McClellan 1960; Jeffery and Saenger 1991; Berstein et al 1994). Based on the results of various workers on hydrogen bonding (Nishio and Hirota 1989; Nishio et al 1995, 1998; Aakeroy and Seddon 1993a,b; Aakeroy 1997), Desiraju and Steiner (1999) tried to make some empirical rules on the distance and angle cut-off criteria on mixed kind of organic molecules.

The geometry of intra- and intermolecular hydrogen bonds as obtained is presented in tables 3 and 4, respectively and each table has been followed by brief observations made on the basis of general data as presented in table 2 .

Some of the properties of very strong, strong and weak hydrogen bonds as tabulated by Desiraju and Steiner in an International monogram on crystallography (1999) in case of a variety of hydrogen bonds as retrieved from Cambridge Crystal Data Centre (UK) are presented in table 2.
All the parameters for e.g. bond lengths $d(\mathrm{H}$...A) $\AA$, $\mathrm{D}(\mathrm{X}$...A $) \AA$ etc have been compared with our own data and the following have been observed: (i) The average $\mathrm{D}$ (X...A) $\AA$ value i.e. $2.6 \AA$ in the present case i.e. for the ten alkaloids, does fall within the range as suggested for "strong" hydrogen bond, (ii) the average $d(\mathrm{H}$...A) $\AA$ value i.e. $2 \cdot 4 \AA$ in the present case also, fall under the category of "weak" hydrogen bonds, and (iii) so far as the average angular value i.e. $130 \cdot 8^{\circ}$ of $\mathrm{C}-\mathrm{H} . . . \mathrm{O}, \mathrm{O}-$ $\mathrm{H}$... O and $\mathrm{C}-\mathrm{H} . . . \mathrm{N}$ interactions is concerned, the range as suggested by Desiraju for "weak" hydrogen bonds is

Table 1. Some selected C-N $(\AA)$ bond distances and C-N-C $\left({ }^{\circ}\right)$ bond angles.

\begin{tabular}{|c|c|c|}
\hline Molecule & $\mathrm{C}-\mathrm{N}(\AA)$ & $\mathrm{C}-\mathrm{N}-\mathrm{C}\left({ }^{\circ}\right)$ \\
\hline I & $\begin{array}{l}\mathrm{C} 11-\mathrm{N} 12=1.488 \\
\mathrm{C} 14-\mathrm{N} 12=1.441 \\
\mathrm{C} 13-\mathrm{N} 12=1.467\end{array}$ & $\begin{array}{l}\text { C13-N12-C11 }=114 \cdot 3 \\
\text { C14-N12-C11 }=109 \cdot 0 \\
\text { C14-N12-C13 }=113 \cdot 0\end{array}$ \\
\hline II & $\begin{array}{l}\text { C6-N7 = } 1 \cdot 059 \\
\text { C8-N7 = } 1.490 \\
\text { C3a-N7 = } 1.517\end{array}$ & $\begin{array}{l}\text { C6-N7-C13a = 111.8 } \\
\text { C6-N7-C8 = 109·3 } \\
\text { C8-N7-C13a = 111.5 }\end{array}$ \\
\hline III & $\begin{array}{l}\mathrm{C} 1-\mathrm{N} 10=1 \cdot 460 \\
\mathrm{C} 3 \mathrm{~A}-\mathrm{N} 4=1.288 \\
\mathrm{C} 3 \mathrm{~A}-\mathrm{N} 10=1 \cdot 370 \\
\mathrm{C} 9-\mathrm{N} 10=1.383 \\
\text { C4A-N4 }=1.401\end{array}$ & $\begin{array}{l}\mathrm{C} 3 \mathrm{~A}-\mathrm{N} 4-\mathrm{C} 4 \mathrm{~A}=115 \cdot 9 \\
\mathrm{C} 3 \mathrm{~A}-\mathrm{N} 10-\mathrm{C} 9=123 \cdot 4 \\
\mathrm{C} 1-\mathrm{N} 10-\mathrm{C} 9=123 \cdot 5 \\
\mathrm{C} 1-\mathrm{N} 10-\mathrm{C} 3 \mathrm{~A}=113 \cdot 0\end{array}$ \\
\hline IV & $\begin{array}{l}\mathrm{C} 1-\mathrm{N} 14=1 \cdot 512 \\
\mathrm{C} 11-\mathrm{N} 14=1.405 \\
\mathrm{C} 13-\mathrm{N} 14=1.335 \\
\mathrm{C} 13-\mathrm{N} 6=1.335 \\
\mathrm{C} 15-\mathrm{N} 6=1.396\end{array}$ & $\begin{array}{l}\text { C13-N6-C15 =122.1 } \\
\text { C11-N14-C13 = 122.4 } \\
\text { C1-N14-C13 = 120.4 } \\
\text { C1-N14-C11 }=117 \cdot 2\end{array}$ \\
\hline $\mathrm{V}$ & $\begin{array}{l}\mathrm{C} 2-\mathrm{N} 1=1.460 \\
\mathrm{C} 6-\mathrm{N} 1=1.458\end{array}$ & $\mathrm{C} 2-\mathrm{N} 1-\mathrm{C} 6=114 \cdot 5$ \\
\hline VI & $\begin{array}{l}\mathrm{C} 13-\mathrm{N} 5=1 \cdot 419 \\
\mathrm{C} 14-\mathrm{N} 5=1 \cdot 366 \\
\mathrm{C} 15-\mathrm{N} 5=1 \cdot 476 \\
\mathrm{C} 11-\mathrm{N} 10=1.486 \\
\mathrm{C} 14-\mathrm{N} 10=1.373\end{array}$ & $\begin{array}{l}\text { C14-N5-C15 }=118 \cdot 7 \\
\text { C13-N5-C15 }=118 \cdot 8 \\
\text { C13-N5-C14 }=120 \cdot 5 \\
\text { C11-N10-C14 }=120 \cdot 7 \\
\text { C9-N10-C14 }=122 \cdot 8 \\
\text { C9-N10-C11 }=116 \cdot 2\end{array}$ \\
\hline VII & $\begin{array}{l}\mathrm{C} 15-\mathrm{N} 16=1.463 \\
\mathrm{C} 17-\mathrm{N} 16=1.469 \\
\mathrm{C} 21-\mathrm{N} 16=1.462\end{array}$ & $\begin{array}{l}\text { C17-N16-C21 }=111 \cdot 5 \\
\text { C15-N16-C21 }=115 \cdot 3 \\
\text { C15-N16-C21 }=116 \cdot 1\end{array}$ \\
\hline VIII & $\begin{array}{l}\mathrm{C} 2-\mathrm{N} 1=1 \cdot 277 \\
\mathrm{C} 9-\mathrm{N} 1=1 \cdot 390 \\
\mathrm{C} 2-\mathrm{N} 3=1 \cdot 387 \\
\mathrm{C} 4-\mathrm{N} 3=1.409 \\
\mathrm{C} 11-\mathrm{N} 3=1.446\end{array}$ & $\begin{array}{l}\mathrm{C} 2-\mathrm{N} 1-\mathrm{C} 9=117 \cdot 6 \\
\mathrm{C} 4-\mathrm{N} 3-\mathrm{C} 11=117 \cdot 5 \\
\mathrm{C} 2-\mathrm{N} 3-\mathrm{C} 11=121 \cdot 0 \\
\mathrm{C} 2-\mathrm{N} 3-\mathrm{C} 4=121 \cdot 5\end{array}$ \\
\hline IX & $\begin{array}{l}\mathrm{C} 2-\mathrm{N} 1=1 \cdot 325 \\
\mathrm{C} 9-\mathrm{N} 1=1 \cdot 401 \\
\mathrm{C} 2-\mathrm{N} 3=1 \cdot 321\end{array}$ & $\begin{array}{l}\mathrm{C} 2-\mathrm{N} 1-\mathrm{C} 9=121 \cdot 9 \\
\mathrm{C} 2-\mathrm{N} 3-\mathrm{C} 4=128 \cdot 0\end{array}$ \\
\hline$X$ & $\begin{array}{l}\mathrm{C} 2-\mathrm{N} 1=1 \cdot 358 \\
\mathrm{C} 9-\mathrm{N} 1=1 \cdot 380\end{array}$ & $\mathrm{C} 2-\mathrm{N} 1-\mathrm{C} 9=124 \cdot 4$ \\
\hline
\end{tabular}


Table 2. Comparative data for different kinds of hydrogen bonds.

\begin{tabular}{lcccc}
\hline Properties & Very strong & Strong & Weak & Mol. I-X \\
\hline $\mathrm{D}(\mathrm{X}-\mathrm{H} . . . \mathrm{A})$ range $\AA$ & $2 \cdot 2-2 \cdot 5$ & $2 \cdot 5-3 \cdot 2$ & $3 \cdot 0-4 \cdot 0$ & $2 \cdot 51-3 \cdot 68$ \\
$d(\mathrm{H} \ldots \mathrm{A})$ range $\AA$ & $1 \cdot 2-1 \cdot 5$ & $1 \cdot 5-2 \cdot 2$ & $2 \cdot 0-3 \cdot 0$ & $1 \cdot 56-2 \cdot 81$ \\
$\theta(\mathrm{X}-\mathrm{H} . . \mathrm{A})$ range $\left(^{\circ}\right)$ & $175-180$ & $130-180$ & $90-180$ & $99-176$ \\
Effect on crystal packing & Strong & Distinctive & Variable & Variable \\
Utility in crystal engineering & Unknown & Useful & Partly useful & Partly \\
\hline
\end{tabular}

Table 3. Geometry of intramolecular $\mathrm{C}-\mathrm{H} \ldots \mathrm{O}, \mathrm{O}-\mathrm{H} \ldots \mathrm{O}$ and $\mathrm{C}-\mathrm{H} \ldots \mathrm{N}$ interactions.

\begin{tabular}{|c|c|c|c|c|}
\hline Molecule* & X-H...A & H...A $(\AA)$ & $\mathrm{X}-\mathrm{A}(\AA)$ & $\mathrm{X}-\mathrm{H} \ldots \mathrm{A}\left({ }^{\circ}\right)$ \\
\hline II & $\mathrm{C}-\mathrm{H} \ldots \mathrm{O}$ & $2 \cdot 51$ & $2 \cdot 99$ & 109 \\
\hline \multirow[t]{2}{*}{$\mathrm{V}$} & C-H...O & $2 \cdot 34$ & $2 \cdot 68$ & 99 \\
\hline & C-H... & $2 \cdot 54$ & $2 \cdot 96$ & 107 \\
\hline \multirow[t]{3}{*}{ VI } & $\mathrm{C}-\mathrm{H} \ldots \mathrm{O}$ & $2 \cdot 19$ & $2 \cdot 66$ & 109 \\
\hline & C-H...O & $2 \cdot 81$ & $3 \cdot 29$ & 109 \\
\hline & $\mathrm{O}-\mathrm{H} \ldots \mathrm{O}$ & $1 \cdot 56$ & $2 \cdot 51$ & 156 \\
\hline \multirow[t]{9}{*}{ VII } & O-H... & $2 \cdot 25$ & $2 \cdot 73$ & 118 \\
\hline & $\mathrm{O}-\mathrm{H} \ldots \mathrm{O}$ & $1 \cdot 83$ & $2 \cdot 64$ & 149 \\
\hline & $\mathrm{C}-\mathrm{H} \ldots \mathrm{N}$ & $2 \cdot 47$ & $2 \cdot 97$ & 110 \\
\hline & C-H...O & $2 \cdot 53$ & $2 \cdot 85$ & 99 \\
\hline & C-H...O & $2 \cdot 58$ & $2 \cdot 97$ & 105 \\
\hline & C-H...O & $2 \cdot 19$ & 2.78 & 118 \\
\hline & C-H...O & $2 \cdot 65$ & $2 \cdot 97$ & 100 \\
\hline & $\mathrm{C}-\mathrm{H} \ldots \mathrm{O}$ & $2 \cdot 48$ & $2 \cdot 94$ & 109 \\
\hline & C-H...O & $2 \cdot 49$ & $2 \cdot 93$ & 107 \\
\hline
\end{tabular}

(i) The overall $d(\mathrm{H} \ldots \mathrm{A})$ range in case of intramolecular interactions comes out to be between 1.56 and $2.81 \AA$, thus making these interactions fall under the category of "strong to weak" interactions; (ii) the overall $\mathrm{D}(\mathrm{X} \ldots \mathrm{A})$ range in case of intramolecular interactions comes out to be between 2.51 and $3.29 \AA$ hence making these interactions fall under the category of "strong to weak" interactions, and (iii) the $\theta$ range i.e. $99-149^{\circ}$ in case of intramolecular interactions fall under the category of "weak" interactions.

in conformity with the angular range we obtained in all the ten alkaloids.

\section{Outlook}

The quest of researchers world over is mainly to study the matter in all forms. All kinds of materials, irrespective of their application or utility to the industry or society, need to be characterized by making use of various available scientific techniques. In this paper, we have tried to provide an insight into the chemical and crystallographic aspects of alkaloids which are considered very potent especially for their use in medical science. The literature on the chemical and crystallographic aspects of alkaloids is available as isolated papers but there appears to be no documented study which could provide a detailed account of the three-dimensional structure of some alka- loids especially with emphasis on the role of hydrogen bonding in organic molecular assemblies. The main purpose of the study is to ascertain whether the results of these ten molecules are in conformity with what is available in the literature for analogous structures. It has been observed that some of the geometrical and structural parameters including the geometry of individual ring systems is in consonance with the established scheme and in some cases, few deviations in terms of $\mathrm{C}-\mathrm{N}$ bond distances and $\mathrm{C}-\mathrm{N}-\mathrm{C}$ bond angles have also been observed.

Currently, research in hydrogen bonding concentrates on the weakest and the strongest species. In the field of weak hydrogen bonding, more publications now appear than ever, and progress is far more rapid than a few years ago. Therefore, it is presumed to have substantial progress in a number of important fields, such as the role on $\mathrm{C}-\mathrm{H}$...O, C-H...N etc hydrogen bonds in molecular recognition, in the self-assembly of molecules, in the design 
Table 4. Geometry of intermolecular $\mathrm{C}-\mathrm{H} \ldots \mathrm{O}, \mathrm{O}-\mathrm{H} \ldots \mathrm{O}$ and $\mathrm{N}-\mathrm{H}$... O interactions.

\begin{tabular}{|c|c|c|c|c|}
\hline Molecule & X-H...A & H...A $(\AA)$ & $\mathrm{X}-\mathrm{A}(\AA)$ & $\mathrm{X}-\mathrm{H} \ldots \mathrm{A}\left({ }^{\circ}\right)$ \\
\hline \multirow[t]{4}{*}{ II } & $\mathrm{C}-\mathrm{H} \ldots \mathrm{O}$ & $2 \cdot 43$ & $3 \cdot 41$ & 154 \\
\hline & $\mathrm{C}-\mathrm{H} \ldots \mathrm{O}$ & 2.43 & $3 \cdot 30$ & 142 \\
\hline & $\mathrm{C}-\mathrm{H} \ldots \mathrm{O}$ & $2 \cdot 65$ & $3 \cdot 46$ & 147 \\
\hline & $\mathrm{C}-\mathrm{H} \ldots \mathrm{O}$ & $2 \cdot 56$ & $3 \cdot 41$ & 132 \\
\hline \multirow[t]{2}{*}{ III } & $\mathrm{O}-\mathrm{H} \ldots \mathrm{O}$ & 1.90 & $2 \cdot 84$ & 170 \\
\hline & O-H... & $1 \cdot 68$ & $2 \cdot 71$ & 178 \\
\hline \multirow[t]{2}{*}{ V } & $\mathrm{N}-\mathrm{H} \ldots \mathrm{O}$ & $2 \cdot 35$ & $3 \cdot 23$ & 144 \\
\hline & $\mathrm{C}-\mathrm{H} \ldots \mathrm{O}$ & $2 \cdot 37$ & $3 \cdot 11$ & 131 \\
\hline \multirow[t]{3}{*}{ VI } & $\mathrm{C}-\mathrm{H} \ldots \mathrm{O}$ & $2 \cdot 67$ & $3 \cdot 43$ & 131 \\
\hline & C-H... & $2 \cdot 70$ & $3 \cdot 59$ & 159 \\
\hline & $\mathrm{C}-\mathrm{H} \ldots \mathrm{N}$ & $2 \cdot 78$ & $3 \cdot 48$ & 123 \\
\hline VIII & $\mathrm{C}-\mathrm{H} \ldots \mathrm{O}$ & $2 \cdot 79$ & $3 \cdot 68$ & 153 \\
\hline \multirow[t]{2}{*}{$X$} & $\mathrm{~N}-\mathrm{H} \ldots \mathrm{O}$ & 1.98 & $2 \cdot 83$ & $176 \cdot 2$ \\
\hline & $\mathrm{C}-\mathrm{H} \ldots \mathrm{O}$ & $2 \cdot 57$ & $3 \cdot 41$ & $150 \cdot 4$ \\
\hline
\end{tabular}

*Only molecules II, V and VI exhibit both intra- and intermolecular.

(i) The overall $d(\mathrm{H} \ldots \mathrm{A})$ range in case of intermolecular interactions comes out to be between 2.35 and $2.79 \AA$, thus making these interactions fall under the category of "strong to weak" interactions; (ii) the overall $\mathrm{D}(\mathrm{X}$...A) range in case of intermolecular interactions comes out to be between 2.83 and $3.68 \AA$ hence making these interactions fall under the category of "strong to weak" interactions; and (iii) the $\theta$ range i.e. 123$176^{\circ}$ in case of intermolecular interactions fall under the category of "weak" interactions.

of crystal structures, in the architecture and function of biological systems. The present study has provided us a broad base to carry out further work by taking into our fold some more data. It is hoped that study of this kind might help us in bringing the role of hydrogen bonding in alkaloids to a broader end.

\section{Acknowledgements}

One of the authors (Rajnikant) is thankful to his collaborators who have supplied the samples for X-ray analysis and also to some of his research students who have carried out crystallographic research on these molecules as a part of their Ph D programme. The findings as reported in this paper are a part of the $\mathrm{Ph} \mathrm{D}$ work of Ms Kamni, one of the co-authors in this paper. Rajnikant is also thankful to the University Grants Commission (UGC), Govt. of India, for funding under DRS project no. F. 10-82/2001.

\section{References}

Aakeroy C B 1997 Acta Crystallogr. B53 569

Aakeroy C B and Seddon K R 1993a Chem. Soc. Rev. 22397

Aakeroy C B and Seddon K R 1993b Z. Naturforsch. b48 1023
Allen F H, Kennard O and Watson D G 1987 J. Chem. Soc. Perkin. Trans. 2 SI

Anshu Sawhney 2003 Three-dimensional structure elucidation of some nitrogen containing molecules using crystallographic and computational techniques, $\mathrm{Ph}$ D Thesis, University of Jammu, Jammu Tawi

Atal C K 1980 Chemistry and pharmacology of vasicine: A new oxytocic and abortifacient (Jammu: Regional Research Laboratory)

Babita M 1994 Chemistry of natural products Ph D Thesis, Regional Research Laboratory, Jammu Tawi

Baker B R, Koehler R, Goodman L and De Graw J 1961 Org. Chem. 261156

Bergman J, Brynolf A, Elman B and Vuorinen E 1986 Tetrahedron 423697

Berg S S and Lucas J M S 1961 Nature 18964

Berstein J, Etter M C and Leiserowitz L 1994 The role of hydrogen bonding in molecular assemblies; in Structure correlation (eds) H-B Burgi and J D Dunitz (Weinheim: VCH) 2 p. 431

Bhandary K K, Ramasubbu N and Joshi B S 1990 Acta Crystallogr. Struct. Commun. C46 1704

Bruderer H, Metzger J, Brossi A and Dally J J 1976 Helv. Chim. Acta 592793

Byke R and Vandyke C 1997 Cocaine (eds) R C Peterson and R C Stillman (Washington ) 97

Cameron A F, Hair N J, Greengrass C W and Romage R 1974 Acta Crystallogr. B30 282

Chopra I C, Kohli J D and Handa K L 1945 Indian J. Med. Res. 33139

Chopra R N 1958 Chopra's indigenous drugs of India 2nd Ed. p. 412

Choudhary B I and Panda S K 2003 Science Reporter 4057

Desiraju G J and Steiner T 1999 The weak hydrogen bond (New York: International Union of Crystallography)

Duax W L and Norton D A 1975 Atlas of steroid structure (New York: Plenum) I

Ebel F, Rupp W and Tranth O 1958 Chem. Abstr. 521639

Farrugia L J 1997 J. Appl. Cryst. 30565

Fischer E, Knippel M and Wollin K M 1983 J. Prakt. Chem. 325261

Gorinsky C and Moss D S 1973 J. Cryst. Mol. Struct. 3299

Govindachari T R and Narasimhan N S 1955 J. Chem. Soc. 1563

Govindachari T R, Nagarajan K and Viswanathan N 1965 Tetrahedron Letts 241907

Gupta B D and Banerjee S K 1994 Private Communication, Regional Research Laboratory, Jammu Tawi

Hua D H et al 1997 J. Org. Chem. 626888

Jeffery G A and Saenger W 1991 Hydrogen bonding in biological structures (Berlin: Springer-Verlag)

Jones G 1977 Chemistry of heterocyclic compounds: I. Quinolines (Chichester: Wiley) 32 p. 93

Joshi B S, Desai H K, Pelletier S W and Newton M G 1992 J. Crystallogr. Spectrosc. Res. 22477

Joshi B S, Newton M G, Lee D W, Barber A D and Pelletier S W 1996 Tetrahedron Asym. 725

Kistenmacher T J and Shigematsu T 1974 Acta Crystallogr. B30 1528

Klyne W and Prelog V 1996 Experientia XVI 521

Magotra D K, Gupta V K, Rajnikant, Goswami K N, Thappa R K and Agarwal S G 1996 Acta Crystallogr. C52 1491 
Mahajan B 1995 Chemistry of natural products Ph D Thesis, Regional Research Laboratory, Jammu Tawi

Mclean E 1970 Parm. Rev. 22429

Mehta D R, Naravane J S and Desai R M 1963 J. Org. Chem. 28445

Moss D S and Watson F E 1984 Acta Crystallogr. C40 1960

Nardelli M 1983 Comput. Chem. 795

Newell S W et al 1998 Int. J. Oncol. 12433

Nishio M and Hirota M 1989 Tetrahedron 457201

Nishio M, Umezawa Y, Hirota M and Takeuchi Y 1995 Tetrahedron $\mathbf{5 1} 8665$

Nishio M, Hirota M and Umezawa Y 1998 The CH/ $\pi$. Evidence, nature and consequences (New York: Wiley) p. 4

Picorari P, Renaldi M and Antolini L 1992 Acta Crystallogr. C48 2027

Pimentel G C and McClellan A L 1960 The hydrogen bond (San Francisco: Freeman)

Rajnikant 1988 Determination of crystal and molecular structure of some medicinally important compounds by X-ray crystallographic techniques, Ph D Thesis, University of Jammu, Jammu Tawi

Rajnikant 2001 Mol. Mater. 14165

Rajnikant, Goswami K N, Yadava V S, Padmanabhan V M and Banerjee S K 1993 Acta Crystallogr. C49 505

Rajnikant, Watkin D and Tranter G 1995 Acta Crystallogr. C51 1452, 2071, 2161, 2388

Rajnikant, Gupta V K, Singh A, Lal M and Varghese B 1996 Mol. Mater. 6253

Rajnikant, Gupta V K, Singh A, Lal M, Manisekaran T and Rangari V D 1998a Mol. Mater. 9227

Rajnikant, Gupta V K, Lal M, Rangari V D, Belsare D P, Soni B S and Varghese B 1998b Mol. Mater. 9131

Rajnikant, Gupta V K and Singh A 2000 Crystallogr. Rep. 45611

Rajnikant, Gupta V K and Lal M 2001a Crystallogr. Rep. 46230

Rajnikant, Gupta V K, Deshmukh M B, Varghese B and Dinesh 2001b Cryst. Res. Technol. 361451

Rajnikant, Gupta V K, Suri O P and Lal M 2002a Indian J. Pure \& Appl. Phys. 4059
Rajnikant, Gupta V K, Deshmukh M B, Varghese B and Dinesh 2002b Crystallogr. Rep. 47449

Sharma S D 1985 X-ray analysis of crystal structure of some organic compounds, Ph D Thesis, University of Jammu, Jammu Tawi

Sharma S D, Gupta V K, Goswami K N and Padmanabhan V M 1993 Cryst. Res. Technol. 281115

Sheldrick G M 1986 SHELXS86 program for the solution of crystal structures (Germany: University of Gottingen)

Sheldrick G M 1993 SHELXS93 program for the refinement of crystal structures (Germany: University of Gottingen)

Sheldrick G M 1997a SHELXS97 program for crystal structure determination (Germany: University of Gottingen)

Sheldrick G M 1997b SHELXL97 program for refinement of crystal structures (Germany: University of Gottingen)

Siegfied L, Karl D, Guenther W, Herwart A and Dieter I 1992 Chem. Abs. 11634567

Steiner T 1995 C-H...O hydrogen bonding in crystals, Cryst. Rev. Institut fur Kristallographie, Freie Universitat Berlin, Takustrabe, D-14195 Berlin, Germany 6

Stout G H and Jensen L H 1968 X-ray structure determination (New York: Macmillan) p. 315

Stroud R M 1973 Acta Crystallogr. B29 690

Sutton L E 1965 Tables of interatomic distances and configuration in molecules and ions (London: The Chemical Society)

Thappa R K, Agarwal S G, Dhar K L, Gupta V K and Goswami K N 1996 Phytochemistry 421485

Wahab M A 1999 Solid state physics (New Delhi: Narosa Publishing House) p. 101

Winterstein E and Trier G 1910 Die Alkaloide, eine Monographie der naturlichen Basen, Borntrager, Berlin

Wong-Ng W and Nyburg S C 1979 Canadian J. Chem. 57 157

Yates F S 1984 Comprehensive heterocyclic chemistry (eds) A R Katrizky and C W Rees (New York: Pergamon) 2 p. 511

Zacharias D and Glusker J P 1988 Acta Crystallogr. Cryst. Struct. Commun. C44 1656 